\title{
Research on Joint Construction of Art Practice Teaching System by Sino-Russian Colleges
}

\author{
Zhongfeng $\mathrm{Fu}$ \\ College of Art and Design \\ Heihe University \\ Heihe, Heilongjiang, China 164300
}

\begin{abstract}
Along with the deepening of reform and opening up, China's education has also entered into the era of globalization. China and Russia main a friendly relationship, and joint school-running between China and Russia has become a popular trend, moreover, the joint construction of art practice teaching system by Sino-Russian colleges has obtained certain achievements. However, some problems still exist in the process of teaching system construction, which need to be perfected. Joint construction of art practice teaching system by SinoRussian colleges is of important significance for China to carry out international education cooperation. (This paper has researched and discussed the achievements, problems and suggestions of joint construction of art practice teaching system by Sino-Russian colleges based on the description of conditions for the joint construction of art practice teaching system by SinoRussian colleges.
\end{abstract}

Keywords-Sino-Russian; colleges; joint construction; art practice teaching; innovation; teaching reform

\section{INTRODUCTION}

At present, China is in the new period of reform and opening-up, and the fields have been expanded to education. Economic globalization has led to education globalization, so there are more and more students go abroad to study. Moreover, another new trend, namely, joint school-running is rising gradually, among which, one of the more important ones is the Sino-Russian joint school-running. China and Russia are neighbors, and since China's reform and opening up, exchanges between the two countries have become more and more frequent. On the premise of friendly relationship between China and Russia, the two countries' education cooperation also develops gradually. 19 colleges including Heihe University and Northeast Forestry University in China's Heilongjiang province have successively developed cooperation in running schools with Russia. And in the process of teaching system construction, the two countries have achieved important achievements in terms of art practice teaching system construction.

\section{CONDITIONS FOR JOINT CONSTRUCTION OF ART PRACTICE TEACHING SYSTEM BY SINO-RUSSIAN COLLEGES}

Joint construction of art practice teaching system by Sino-

This paper is the phased research achievement of academic backbone funding project of Heihe University, and the phased research achievement of higher education teaching reform project of Heihe University, Project No.: XJG1410.
Russian colleges shall be conducted under mature conditions, and cultural exchanges between China and Russia as well as the creation of practice teaching base have become an indispensable assistant for Sino-Russian joint school-running.

\section{A. Sino-Russian Cultural Exchange}

Since the reform and opening, Sino-Russian relationship is improved gradually, and exchanges between the two countries are also increasing. The China Year and Russia Year have been held respectively in 2006 and 2007. But the younger generation knows very little about the culture of the two countries. Therefore, China encourages exchanges between teenagers of the two countries to understand each other's culture and strengthen cultural integration. The integration of cultural exchanges between the two countries in the art field has promoted joint construction of art practice teaching system.

\section{B. Creation of Practice Teaching Base}

First of all, the Sino-Russian art practice teaching base has provided a venue to joint construction of art practice teaching system between China and Russia. Heilongjiang Heihe University started to build this base in 2008. It is supported by the national special construction funds. In addition, Heihe University has established the Sino-Russian applied undergraduate talents cultivation model experimental area and art experimental teaching demonstration center at provincial level for drawing major of Fine Art Department. These projects have greatly promoted the construction of SinoRussian art practice base, which will help to achieve joint school-running. Second, because Russia has the high quality teaching resources, so sufficient introduction of high quality education resources from Russia can strengthen the discipline of art. It is easy for China to introduce Russian profound art teaching resources and the high quality teacher resources as China is adjacent to Russia, enabling students to contact Russia closely and feel the Russian national culture, thus to have a deeper and broader understanding of art in the art practice teaching system.

\section{ACHIEVEMENTS OF JOINT CONSTRUCTION OF ART Practice Teaching System By SinO-RUSSIAN COLLEGES}

Many gratifying results have been achieved since the joint construction of art practice teaching system by Sino-Russian colleges, including creating featured joint-teaching classroom, 
innovation of characteristic specialty, teaching system reform, etc.

\section{A. Create Featured Joint-teaching Classroom}

The famous teachers from both China and Russia will give lessons in the art practice teaching base. The introduction of high quality teaching resources from Russia has provided a platform for the domestic colleges and Russian colleges to carry out art exchange and cooperation, and has gradually formed the practice teaching system of "two countries, one classroom" with the characteristic of Sino-Russian joint school-running. Set up the development concept of "integration, practice, innovation" in art teaching, emphasize the importance of practice teaching in applied talents cultivation, supplement the deficiency of classroom theory with various forms of practice, to effectively improve students' artistic skills.

\section{B. Innovation of Featured Professional Concept}

In the process of joint construction of art practice teaching system, we shall comprehensively implement the scientific development concept, set up the school-running concept of based on students' and teachers' development and pay attention to student's own development. Sets up the characteristic professional consciousness, and seek development on characteristic specialty. Characteristic specialty concept affects the development direction of specialty construction. Therefore, the reform in professional construction and teaching concept must be achieved first of all for characteristic specialty construction. Abandon the traditional teaching idea and set up new ideas, to adapt to the need of teaching reform. At the same time, actively introduce the teaching resources such as courses, textbooks and teaching staff from Russian art colleges of higher education, making the joint construction of are practice teaching system more special.

\section{Teaching System Reform}

First of all, the teaching system reform has been conducted. Modify from the aspects of teaching syllabus and teaching plan, introduce the painting course from Russian painting art colleges of higher education as appropriate, introduce Russia's composing style and consciousness, and compare Russian art teaching method and teaching mode with that of China, so as to develop specific teaching reform scheme; Second, teachers and students between China and Russia have different creative consciousness and styles, so the mutual learning and communication between China and Russia, as well as their mutual complementation have promoted the joint construction of art practice teaching system; finally, strengthen the cultivation of applied talents, change the single mode of classroom teaching, strengthen experiment and practice teaching, to cultivate the students' application ability and practice ability, and increase the proportion of practice teaching in the total credit.

\section{SignificAnCE OF JOINT CONSTRUCTION OF ART} PRACTICE TEACHING SySTEM By SinO-RUSSIAN COLLEGES

\section{A. Provide Experience for Sino-Russian Joint School-running}

The joint construction of art practice teaching system by Sino-Russian colleges has enriched the experience of SinoRussian joint school-running and teaching practice. Its research results are widely promoted in domestic provinces, providing platform for deeper education cooperation between China and Russia in the future. And also provides experience for China to carry out joint school-running with other countries, making China's international education cooperation more and more perfect.

\section{B. Innovative Teaching Mode, Broaden the Students' Horizons}

The introduction of Russian high quality teaching resources is beneficial to the reform of teaching mode in China. Develop the teaching mode more suitable for students' growth through comparing and integration the teaching modes of the two countries and their mutual complementation. In the teaching process, the acceptance and understanding of different cultures and customs is advantageous to the innovation of art workers' inspiration in China. Different art creation consciousnesses and creation styles between China and Russia have broadened the students' horizons and no longer constrained by domestic art style, so as to have the courage to innovate and practice, to create a new art world in the differences.

\section{Beneficial to the Communication in Other Fields between China and Russia}

The construction of art practice teaching system in SinoRussian colleges has not only promoted the art exchanges between China and Russia in art field, but also the communication in other fields. First of all, Sino-Russian joint school-running has promoted cultural exchanges between the two countries. Chinese learning has sprung up in Russia, and more and more Chinese people start to learn Russian. Different customs and habits make the two countries know more about each other, accelerating cultural integration. Secondly, SinoRussian joint school-running has driven economic development of the two countries, and sending students to each other's country has also promoted the economic interaction and development between the two countries. Finally, with more and more Sino-Russian joint school-running projects, the political exchanges between the two countries are more stable, providing good international development environment for China.

\section{PROBLEMS EXIST IN JOINT CONSTRUCTION OF ART PRACTICE TEACHING SYSTEM BY SiNO-RUSSIAN COLLEGES}

While obtaining great achievements in joint construction of are practice teaching system by Sino-Russian colleges, we should also see the problems existing in the process of SinoRussian joint school-running. 


\section{A. Lack of Institutional Guarantee}

In the process of joint construction of art practice teaching system by Sino-Russian, certain contradictions will occur between the two parties. Sino-Russia joint school-running has a short history and lack of specific laws and regulations safeguard. In the process of school-running, with the expanding of cooperation scope, conflicts between the two counties will be expanded for their own interests. For example, there is no specific standard for the fees of overseas students, and the overseas students lack the personal safety security in foreign country, and they are not familiar with the life abroad, and lack of understanding of medical treatment, traffic and culture, all these are likely to harm their own safety.

\section{B. Communication Difficulties}

In the process of joint construction of art practice teaching system, languages between China and Russia are different, and students who can speak Russian are relatively few, even if English is used, difficulties still exist in daily life communication due to students' uneven English level. In the joint school-running, friction and collision are inevitable due to different cultures and customs as well as different understandings and styles in the field of art, and even the national discrimination exist, all of these will cause trouble to joint construction of art teaching system.

\section{Centralized Regional Distribution of Overseas Students}

Colleges of China and Russia send students mutually in the process of joint construction of art practice teaching system, but the regions for overseas students are concentrated. As a result they can't really integrate into life in foreign country living together with their compatriots. Their foreign language level can't be improved as they still speak Chinese. For example, the Chinese students under Heilongjiang joint school-running are mainly concentrated in the Russian Far East, and they still speak Chinese in daily life. After graduation, they can't find a suitable job in Russia because of the language problem. And after combining back to home, their foreign language level that should have been their employment advantage, but due to a lack of exercise, their foreign language level is still not high. As a result, overseas students' own ability hasn't been improved, and they still the great employment pressures after returning.

\section{Inadequate Understanding of Art}

In the process of joint construction of art practice teaching system between China and Russia, each country will send teachers and students. When students contact foreign art style, they may be unable to understand the foreign art course, art theory and styles due to lack of practice and experience in the process of learning. Mandatory infusion education is undesirable, and the general acceptance of foreign art education may cause the confusion of knowledge. Facing the differences in culture and art between the two countries, we shall pay more attention to their respective characteristics and integration in term of art in the process of teaching.

\section{SUGGESTIONS FOR JOINT CONSTRUCTION OF ART} PRACTICE TEACHING SYSTEM BY SINO-RUSSIAN COLLEGES

In the face of problems exist in joint construction of arts teaching practice system by Sino-Russian colleges, measures should be taken in a timely manner.

\section{A. Improve Institutional Guarantee, to Ensure Personal Safety}

In the process of joint construction of teaching system, conflict between the two parties is inevitable due to differences in culture and interests. Both China and Russia shall improve suitable laws and regulations for education under the trend of internationalization of higher education, to regulate all aspects of joint school-running and eliminate the conflict. Provide personal safety guarantee for the overseas students, establish and improve medical insurance system and tuition payment system, etc. for students in foreign countries. Perfect management system is the key to the success of joint schoolrunning.

\section{B. Strengthen Students' Adaptability Education}

First of all, strengthen the students' self protection awareness, and require them to learn about knowledge of the two countries in terms of customs, medical treatment, transportation, culture, self rescue and law, to protect their own security. Second, strengthen knowledge education on students, to improve the overseas students' foreign language level and the learning of cultures between China and Russia, providing students with the ability of language communication and to live independently. Through the joint construction of art practice teaching system to truly improve students' ability and cultivate valuable talents. Finally, strengthen students' tolerance and respect for different cultures, enabling them to observe the customs of foreign country and learn to tolerate different cultures between China and Russia.

\section{Establish the Dispersion Pattern of Overseas Students}

In the process of joint construction of art practice teaching system by Sino-Russian colleges, the overseas students shall be arranged in a scattered manner, to enable them to truly integrate into the country's real life and experience different cultural life, which is beneficial to improve their foreign language ability. And to truly experience differences and tolerance in the process getting along with people from different countries, to improve their living ability, feel the difference between the two countries in terms of art subject, so as to influence the individual, improve their creative ability and innovate creation style.

\section{Improve Teaching Cooperation Pattern, Enhance the Quality of Teachers}

In order to construct the art practice teaching system joint between Sino-Russian colleges, we should perfect the teaching cooperation pattern, improve teachers' quality, and formulate the cultivation scheme according to the characteristics of students, provide targeted guidance to the understanding of different cultures. Foreign culture shall not be denied blindly in the teaching process. To the contrary, we shall be tolerant 
and actively absorb foreign art principle, and conduct integration and innovation, so as to cultivate the students who are more excellent.

\section{CONCLUSION}

The joint construction of art practice teaching system is conducted in the good relationship between China and Russia, and the two countries have provided the supports in terms of funds, policies and education resources to the joint construction which has obtained remarkable achievements, playing a huge role in promoting the development of art of the two countries. But a series of problems still exist in the process of joint school-running, which require us to take measures to improve the joint construction of art practice teaching system between the two countries. The joint construction of art practice teaching system between the two countries also plays a very important role in harmonious development of SinoRussian relations as well as political and economic exchanges between China and Russia. The education cooperation between China and Russia will be more and more perfect based on Sino-Russian joint construction of art practice teaching system.

\section{REFERENCES}

[1] Guo Jianwei. Research on Problems Exist in Sino-Foreign Joint Schoolrunning and Countermeasures [D]. Northeast Normal University 2011.

[2] Song Liquan. Current Situation of Sino-Russian Joint School-Running in Northern Xinjiang and Reflection on It [J]. China Higher Education Research. 2010(02).

[3] The Fourth Academic Conference of "Sino-Russian Cooperation History and Prospect" [J]. Journal of Heihe University. 2014(04).

[4] Miao Hui. Discussion on Advantages and Prospect of Joint Schoolrunning with Russia [J]. Journal of Qiqihar University (Philosophy and Social Sciences Edition). 2010(06). 